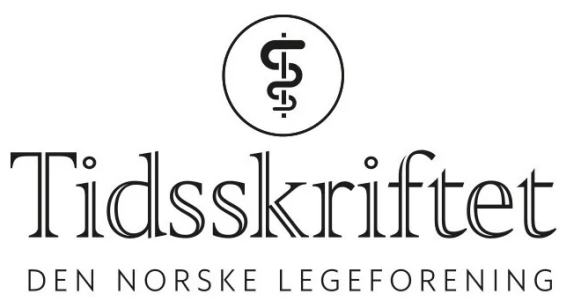

\title{
Covid-19:Vi som tror vi ikke kan hjelpe
}

REDAKSJONELL KOMMENTAR

ØYVIND STOPLE SIVERTSEN

oyvind.stople.sivertsen@tidsskriftet.no

Øyvind Stople Sivertsen er allmennlege i spesialisering og medisinsk redaktør i Tidsskriftet.

Frem til i dag var jeg en på laget. Nå er jeg satt på tribunen med karantene. Det gjør vondt å ikke kunne bidra. 


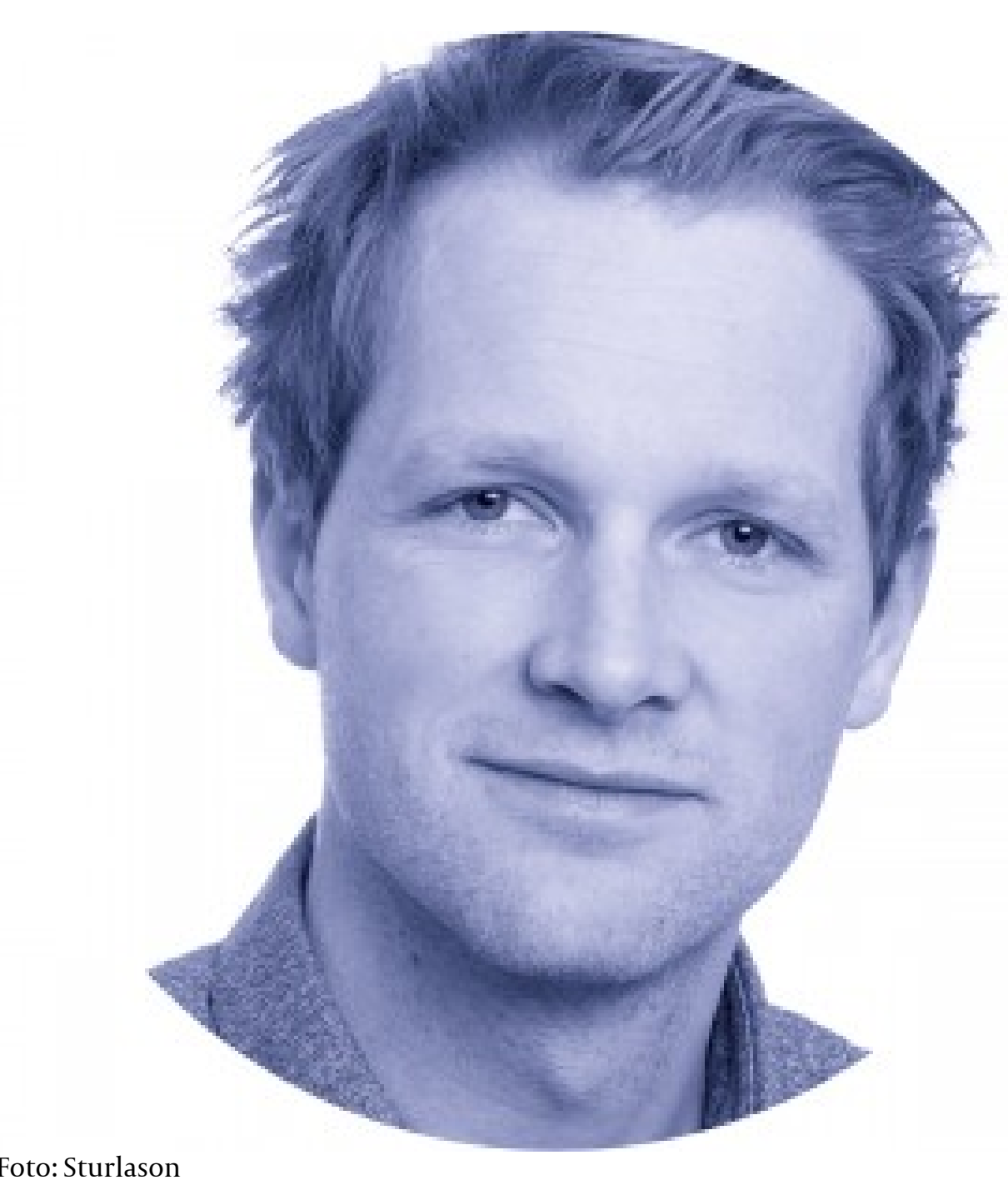

Foto: Sturlason

Det finnes en ordbok for "obskure sorger», samlet og kultivert av John Koenig. Her gis det forklaringer og definisjoner på følelser og tilstander som man kjenner seg igjen i, men som ennå ikke har fått navn. En av dem er kuebiko (1):

«Følelsen av utmattelse du får av å observere meningsløse voldelige handlinger, som tvinger deg til å revurdere inntrykket ditt av hva som kan skje i verden, (...) som får deg til å føle deg som et fugleskremsel, nær ved å sprekke i sømmene, men helt ute av stand til å gjøre annet enn å bare stå der å se på» (min oversettelse).

Tidligere har dette ordet vært treffende for avmakten jeg føler når jeg ser hva vi kan godta av menneskelig lidelse, for eksempel inhumane boforhold i flyktningleirer som Moria. Hvordan vi, inkludert meg selv, ser det som er langt unna, men blir handlingslammet og bare står der.

Når dette skrives, når koronahavet har trukket seg tilbake og vi venter på bølgen, når alle skal ha fått vite at tsunamien er på vei, da sitter jeg i karantene. Et kort besøk i København forrige helg gjorde meg indisponibel til å være på jobb som lege fra ettermiddagen lørdag 14. mars, da regjeringen oppdaterte sine karantenebestemmelser (2 2 ).

Det gjør vondt. Jeg ville bidra. Jeg hadde brettet opp ermene. Jeg var klar.

Jeg er ikke alene. Det er grunn til å tro at hundrevis av norske fastleger sitter i karantene og at mange, mange flere av landets øvrige helsearbeidere gjør det samme. Vi venter. Vi vet ikke helt på hva, selv om vi frykter noe som er ille.

Jeg har jobbet lenge nok i helsevesenet til å forstå at jeg ikke er unik. Min arbeidsmoral deles av mange. Jeg er stolt av å tilhøre en gruppe som man alltid kan stole på, som bestandig gjør det lille ekstra, som sørger for at jobben blir gjort. 
Jeg er stolt av å tilhøre en yrkesgruppe som er så motivert for å hjelpe. Ikke bare yrkesgruppe, men et folk som er så villige til å hjelpe. For dette gjelder ikke bare fastlegene og legevaktlegene, som akkurat nå er i front. Det gjelder ikke bare sykehuslegene, som snart overtar mesteparten av trykket. Det gjelder helsesekretærene, renholderne, de ansatte i ambulansene. De ansatte i dagligvarebutikker, renovasjonsetaten, transportnæringen. Det gjelder lærere, sykepleiere, foreldre og barnevernet.

«Dette er ingen sprint, det er langdistanse. Vi har hver vår rolle, hver vår måte å hjelpe hverandre på»

Barn har fått hverdagen sin endret etter at skole og barnehager stengte. Voksne sitter hjemme alene. De var ensomme før, men er isolerte nå. For oss på tribunen er det mye vi kan gjøre for dem. En prat med et barn om redsel og vonde tanker. En telefon til en man ikke har ringt på en stund.

Facebook-feeden min fylles av indignasjon over de som går utendørs når de ikke bør, de som reiser på hytta når de burde vært hjemme, over statsledere som ikke er handlekraftige nok. Det kommer både fra lukkede grupper for leger og åpne grupper med andre velmenende. Indignasjon er det siste vi trenger. De fleste tar nemlig situasjonen på alvor. De som ikke gjør det, trenger korreks eller støtte.

Samtidig ser jeg bilder av kolleger som bygger om akuttmottak for å forberede strømmen av pasienter. Jeg ser kommuneoverleger over hele landet dele retningslinjer, plakater og mestringsstrategier med hverandre. Jeg får innblikk i smittevernplaner, bygging av feberklinikker, plan B, C og D for scenarioer vi aldri trodde vi skulle oppleve. Jeg ser engasjement, pragmatisme, kamplyst og en uuttømmelig vilje til å hjelpe.

Den kommende uken kan jeg ikke gjøre det jeg trodde jeg skulle gjøre for å bidra i kampen mot koronaepidemien. Men jeg skal ikke la kuebiko fylle meg. Jeg er satt på tribunen, men jeg heier på dere som fremdeles er aktive. Jeg skal støtte dere, slik dere har støttet meg til nå. Dette er ingen sprint, det er langdistanse. Vi har hver vår rolle, hver vår måte å hjelpe hverandre på. For noen innebærer det å jobbe hardt, for andre innebærer det å holde seg unna. I et samfunn er vi alle viktige for hverandre. Det forstår jeg mer og mer i fraværet av en normal hverdag.

\section{LITTERATUR}

1. Kuebiko KJ. I: Dictionary Of Obscure Sorrows.

https://www.dictionaryofobscuresorrows.com/post/38066056235/kuebiko Lest 15.3.2020.

2. Regjeringen. Ny forskrift om karantene etter reiser utenfor Norden.

https://www.regjeringen.no/no/aktuelt/ny-forskrift-om-karantene-etter-reiser-utenfornorden/id2693598/ Lest 14.3.2020.

Publisert: 16. mars 2020. Tidsskr Nor Legeforen. DOI: 10.4045/tidsskr.20.0217

(C) Tidsskrift for Den norske legeforening 2023. Lastet ned fra tidsskriftet.no 26. april 2023. 